\title{
新たな神経疾患治療ターゲット 〜グアニン四重鎖〜
}

塩田 倫史, 矢吹 悌, 朝光 世煌

要約 : よく知られた一般的な DNAの形態は,「B 型 DNA 構造」と呼ばれる右巻き 2 重らせん構造体であ る。一方，DNA はそれ以外にも様々な立体配座「非 $\mathrm{B}$ 型 DNA 構造」を取り得ることが明らかになってい る.さらに, RNAに関しても A 型 2 本鎖 RNA を形成 するステムループだけでなく様々な RNA 構造体が 同定されており, 生命現象に深く関与する。 近年, 非 $\mathrm{B}$ 型 DNA・RNA 構造のひとつであるグアニン四重鎖 (G-quadruplex : G4) 構造の生物学的機能が注目され ている. バイオインフォマティクス解析により，様々 な生物種における G4 構造のゲノム位置が明らかにさ れている.さらに生物学的解析においても, グアニン 四重鎖は DNA 複製，転写，エピジェネティクス修飾， RNA 代謝などの重要な生命現象に関与することが示 唆されている. 本特集では, G4 構造の神経機能にお ける役割を中心に, 神経機能障害の根底にあるメカニ ズムとの関与，および神経疾患の治療標的としての可 能性について述べる.

\section{1.はじめに}

最も研究されている DNAの形態は, B 型 DNA と呼 ばれる右巻き 2 重らせん構造である。 1953 年に, ワト ソン博士とクリック博士はX $\mathrm{X}$ 線結晶構造解析に基づい て，B型 DNA モデルである 2 重らせん構造を明らか にした(1).一方，このワトソンークリック型以外の DNA 構造も存在し, それらは「非 B 型 DNA 構造」と 呼ばれる。これまでに多くの非 B 型 DNA 構造体が報 告されており, 代表例として左巻きらせん $Z$ 型構造 $(2)$, i モチーフ構造 (3), グアニン四重鎖（G-quadruplex： G4）構造 (4) などが挙げられる。これら非 B 型 DNA 構造は, DNA 複製, 転写, 組換え, 修復などの生命現 象に重要な役割を担うことが示唆されている(5).
本特集では, 非 B 型 DNA 構造の中でも神経疾患と の関与が示唆されている G4 構造について述べる. G4 構造はグアニンに富む DNA または RNA 配列内に形成 される核酸高次構造である. 1910 年に, グアニル酸の 濃縮溶液がゲル状になることが初めて報告されたが (6)，この結果はグアニンに富む核酸配列が高次構造 を形成する可能性を示唆するものであった。 その約 50 年後, グアニル酸の濃縮ゲルの特性が X 線回折法に より詳細に調べられ，各グアニンが 2 つの隣接するグ アニンと水素結合し，4つのグアニン分子が正方形の 平面配置をとることが明らかにされた (7)。この平面 構造は現在「Gカルテット」と呼ばれている（図 1a). その後, 生理的塩濃度の条件下で, グアニンに富む一 本鎖 DNAが G カルテットを形成し, 互いの上に積み重 ねられて G4 構造を形成することが示された $(4,8,9)$. G4 構造は, 少なくとも 2 つ隣接グアニンを有する 4 つ のトラクトと 3 つのループ領域で形成される（図 $1 \mathrm{~b}$ ).

G4 構造はその物理学的に高い熱安定性やゲノム上 の領域特性から, 生体内での機能に注目が集まってい る. G4 構造の形成は, DNA 複製, 転写, エピジェネ ティクス, およびRNA 代謝など様々な生物学的機能と 関連する。例えば, DNA にお打る G4 構造 (G4DNA) は, テロメア，有糸分裂および減数分裂の二本鎖切断部位, 転写開始部位，および複製起点において重要な役割を 果たす（10)。さらに, RNAに打ける G4 構造 (G4RNA) は， RNA スプライシング， RNA 輸送から mRNA 翻訳 まで, RNA 代謝の多くの段階に関与する(11)。G4DNA および G4RNAの生命現象における役割について, 詳し い情報はその他の優れた総説を参考にされたい(12-15).

ここでは，これまで報告された G4 構造に関する生 物物理学的エビデンスとバイオインフォマティクス解 析について解説する。 また, 神経生物学における

キーワード : 神経疾患, 非 B 型 DNA・RNA 構造, グアニン四重鎖

熊本大学 発生医学研究所 ゲノム神経学分野（下860-0811 熊本県熊本市中央区本荘 2 丁目 2-1)

E-mail: shioda@kumamoto-u.ac.jp＼cjkstart原稿受領日：2019 年 7 月 16 日，依頼原稿 
a

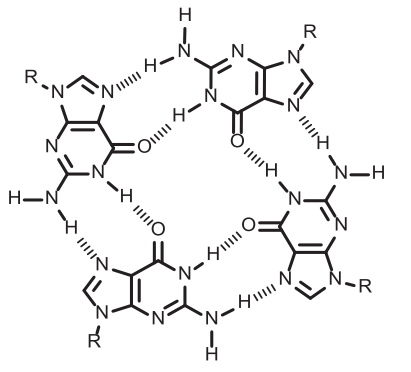

b

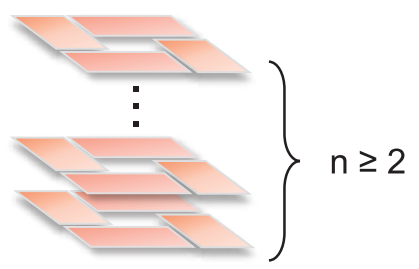

(1)

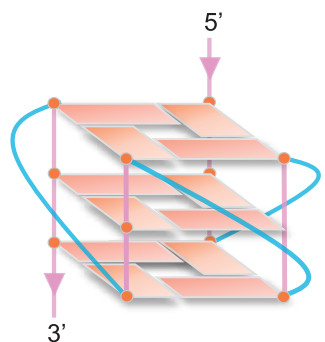

グアニン四重鎖構造

(G-quadruplex; G4)

$5^{\prime}-\mathrm{G}_{\geq 2} \mathrm{~N}_{1-7} \mathrm{G}_{\geq 2} \mathrm{~N}_{1-7} \mathrm{G}_{\geq 2} \mathrm{~N}_{1-7} \mathrm{G}_{\geq 2}-3^{\prime}$

$(\mathrm{N}: \mathrm{A}, \mathrm{C}, \mathrm{G}, \mathrm{T})$

(Loop nt: $n \geq 1-7$ )

図 1 DNA グアニン四重鎖構造の基本概略図

(a) G カルテットの化学構造. (b) DNA グアニン四重鎖構造は, 少な くとも2つまたは 3 つの G カルテットと, 長さが異なる 3 つのループ （1〜7ヌクレオチド）からなる.（文献 104 より一部改変）
G4DNA と G4RNAの予想される役割，および神経疾患 における G4 構造の新規治療標的としての可能性につ いても述べる.

\section{G4 構造のトポロジー解析}

$\mathrm{G} 4$ 構造の形成は, カチオンの結合, 温度, 配向, ループサイズなど，いくつかの要因により影響を受け る $(16,17)$. G4DNA は Gカルテットの中心に一価の 陽イオンが結合することで安定化する。一般的には, $\mathrm{K}^{+}>\mathrm{Na}^{+}>\mathrm{Li}^{+}$の順に G4DNAの安定化作用が強い (18)。ループ長および配列により様々な G4 構造体が 形成され，分子内構造（図 2a）, 二分子構造（図 $2 \mathrm{~b}$ ), 四分子構造 (図 2c), 高次 G カルテット構造 (図 2d), ストランドが同一の配向をもつパラレル型（図 2e), 4 本のうち 1 本だけ逆を向くハイブリッド型（図 $2 \mathrm{f}$ ), 配向が 2 本ずつ交互になるアンチパラレル型（図 $2 \mathrm{~g}$ ) などが報告されている(19-21)，G4RNAも一価の陽イ オンが G カルテットに結合することで安定化するが (22)，G4RNAは G4DNAより熱力学的に安定で構造的 多様性が低い(23). 1〜 5 ヌクレオチドの様々なルー プ長の RNAオリゴヌクレオチド・ライブラリーを使 用した実験の結果，G4RNAトポロジーはループ長に は無関係にパラレル型を形成することが示されている a

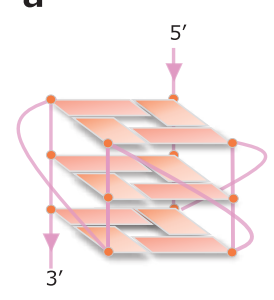

単分子型 b

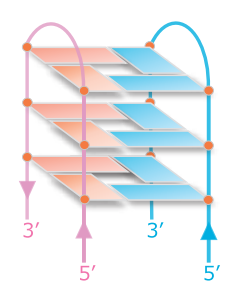

二分子型
C

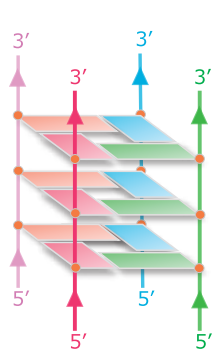

四分子型

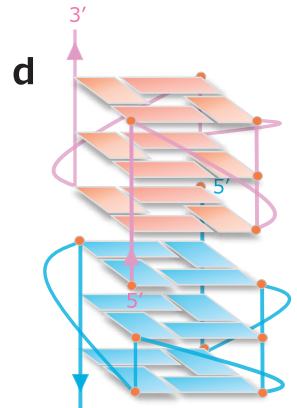

高次 Gカルテット型

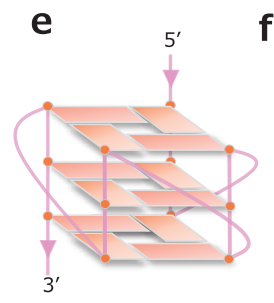

パラレル型

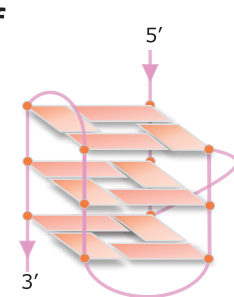

ハイブリッド型 g

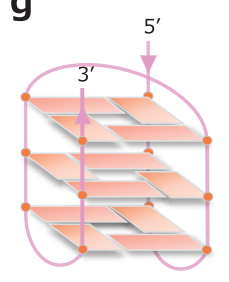

アンチパラレル型 h

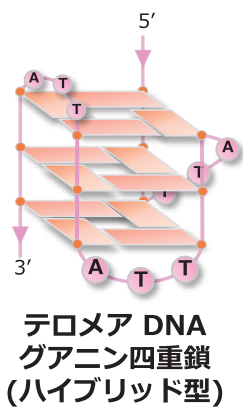

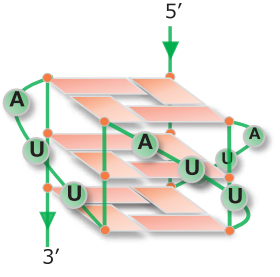

テロメア RNA

グアニン四重鎖

図 2 グアニン四重鎖構造の多様性

(a) 分子内／単分子型，(b) 二分子型，(c) 四分子型，(d) 高次型 $\mathrm{G}$ カルテット型，(e) パラレル型，(f) アンチパラレル型，(g)八イブリッ ド型, (h) K K 含有溶液中のテロメアDNA グアニン四重鎖 (左；八イブリッド型) およびテロメアRNAグアニン四重鎖 (右; 价レル型) の 概略図.（文献 104 より一部改変） 
(24). 一例として，テロメアの構造を図 $2 \mathrm{~g}$ に示した. テロメアは，(TTAGGG) ${ }_{4}$ の配列でハイブリッド型 G4DNAを形成し，(UUAGGG) ${ }_{4}$ の配列でパラレル型 G4RNA を形成する。重要な点として, 上述の G4 構造 のトポロジー解析は全て in vitroによる結果であり, この物理学的性質が in vivoにおける生理的現象とど のように関与するかは未だ明らかではない.

\section{G4 構造のゲノム解析}

これまでに，ヒトゲノムにおける G4DNA 構造のハ イスループットなゲノム解析が行われており, (1) in silico 構造予測，(2)ポリメラーゼ・ストップアッセイ， (3) G4 認識抗体によるクロマチン免疫沈降シーケン シング G4-chromatin immunoprecipitation sequencing （G4 ChIP-Seq）の手法に大別される. しかしながら， それらの結果は手法により大きく異なっている.

G4DNA 構造の in silico 予測に関しては, Quad-Parser (25), QGRS Mapper(26), G4P Calculator(27), QuadBase (28), cGcC score(29)，G4Hunter(30) など，これま でに多くのアルゴリズムが開発されてきた。これらは， ゲノム内で G4DNA 構造形成の可能性を有する配列 potential G-quadruplex-forming sequences (PQS) を予 測する. HeLa 細胞, ヒト線維芽細胞, ヒ上肧性幹細 胞，掞よびヒト人工多能性幹細胞を用いた in silico 予 測の結果, PQS はヒトゲノムに約 300,000 箇所存在し, プロモーター, CpG アイランド, 複製起点, ヌクレオ ソームフリー領域, 5’ 非翻訳領域 5'-untranslated region (5'-UTR)，ファーストエクソンの位置と高度に相関し ていることが示された $(25,27,30,31)$. Quad-Parser を使用した in silico 予測では, アメリカ国立衛生研究 所 National Institutes of Health（NIH）に登録された既 知の遺伝子 38,915 個の 5'-UTR の内, 約 1 割に PQS が 同定された $(25,32)$. しかしながら, in silico 予測は DNA 一次配列から G4 コンセンサス配列である「 $\mathrm{G}_{2 \cdot 3}+$ $\mathrm{N}_{1-7} \mathrm{G}_{2-3}+\mathrm{N}_{1-7} \mathrm{G}_{2-3}+\mathrm{N}_{1-7} \mathrm{G}_{2-3}(\mathrm{~N}=\mathrm{A}, \mathrm{C}, \mathrm{G}, \mathrm{T}) 」$ に基づ き結果を導き出すため, バルジ型モチーフ（非グアニ ン塩基が 3 つのグアニントラック配列の中に含まれる モチーフ) (33) 等の予測には不向きである.さらに, 3 次元的に G4 構造が形成されていることを確認できな い，それらの問題を克服するため, G4 コンセンサス 配列に制限されることなく in silico 予測ができるアルゴ リズムとして G4RNA screener が開発された $(34,35)$.

G4RNA screener は, cGcC score(29), G4Hunter(30), G4NN の 3 つからなる in silico 予測法である. G4NN は，実験的なエビデンスを含めた機械学習（ニュー ラルネットワークアプローチ) を利用しており，人工
知能 artificial intelligence（AI）は，今後の G4 構造 in silico 予測の主流になると思われる。

ゲノムワイドに G4DNA 構造を同定するための別の アプローチとして，ポリメラーゼ・ストップアッセイ がある(36)。この手法は，G4DNA 構造安定剤である ピリドスタチン, または $\mathrm{K}^{+}$の添加により G4DNA 構造 を安定化させ，シーケンス時に G4 構造の位置でポリ メラーゼの進行が停止することを利用する。ポリメ ラーゼ・ストップアッセイでは, ヒト B リンパ球細胞 に扮いてピリドスタチンによって716,310箇所の G4DNA 配列, および $\mathrm{K}^{+} に よ っ て 525,890$ 箇所の G4DNA 配列が同定された (36)。しかしながら，ポリ メラーゼ・ストップアッセイは裸の DNA で解析が行 われるため, クロマチン内の G4DNA 構造を捕えてい ないことが問題点として挙げられる.

クロマチン内の G4DNA 構造を同定するために, G4 ChIP-seq が開発された $(37,38)$. ヒト表皮角化細胞 $\mathrm{HaCaT}$ 細胞のクロマチンでは, 10,560 箇所の G4DNA ピークが同定された。また，G4DNA ピークはユーク ロマチンにおけるヌクレオソームフリー領域に集中し ており，G4DNA構造と転写活性に正の相関関係が見 られた(38). しかしながら，G4 ChIP-seqによって検 出されたピーク数（約 10,000 箇所）は, in silico 予測 によって検出された数（約 300,000 箇所）やポリメ ラーゼ・ストップアッセイによって検出された数（約 700,000 箇所）よりもかなり少ない. 異なる G4 構造認 識抗体による ChIP 解析や次世代シーケンスによって 得られたデー夕の解析法等についてさらなる検討が必 要であろう。

G4RNA 構造に関しても, ハイスループットな in vitro トランスクリプトーム解析が報告されている(39-41). 2 つのヒト細胞株, HEK293T および HeLa 細胞では, G4RNA 構造形成配列が約 15,000 箇所同定されたが, 4,935 箇所が重複し 7,852箇所が重複しない配列で あった(40).ささらに, ケミカルプローブ・シーケンス と逆転写ストッププロファイリングによる in vivo での G4RNA 解析が報告されている(40)。この手法を用い てマウス，ヒト，酵母を分析したところ，ほとんどの G4RNA 領域が折り睍まれていないことが示唆された (40). しかしながら, この方法は薬物反応時間枠内の RNA 構造立体配座を分析するため, 個々の RNAの構 造立体配座, 動的な構造相互変換などを反映していな い(41). 生体内で G4RNA を網羅的に同定するために は，異なる手法を用いて分析する必要がある. 


\section{G4DNA と神経疾患}

G4DNA の異常は, 神経機能障害, 加歯の加速, がん 発症リスクの増加など, ヒトの疾患発症と関連するこ とが示唆されている(42). 神経機能におけるG4DNA の役割は未だ解明されていないが，これまでいくつか の遺伝性神経疾患の病態発症と G4DNA の関与が報告 されている。ここでは，いくつか疾患例を紹介する. 1 つ目は，C9ORF72 遺伝子のもつ GGGGCC（G4C2） リピート配列の異常伸長による家族性の筋萎縮性側 索硬化症および前頭側頭型認知症 C9orf72-mediated amyotrophic lateral sclerosis and frontotemporal dementia （C9ALS/FTD）である(43). C9ORF72 タンパク質の 機能は詳細には不明であるが，G4C2 リピート配列の 異常伸長が疾患の発症に関与すると考えられてお り，C9ALS/FTD 患者の大脳皮質運動野や脊髄の神経 細胞には, G4C2 リピート配列由来 G4RNA の凝集体 （RNA foci）が観察される。 RNA foci は，RNA結合夕 ンパク質等を集積させ, RNA 毒性を呈する。興味深い ことに, G4 構造による RNA foci は液－液相分離 (liquidliquid phase separation : LLPS）を促進し, RNA 結合 タンパク質と共に RNA 顆粒に集積後, 細胞毒性を引 きおこす(44).さらに, G4C2 リピート配列由来 RNAG4 は, repeat-associated non-AUG（RAN）翻訳による ジペプチド反復タンパク質を産生し, 細胞毒性を与え る $(45,46)$. 脆弱 X 関連振戦 / 失調症候群 (fragile Xassociated tremor/ataxia syndrome : FXTAS) も C9ALS/ FTD と同様, グアニンが豊富な領域のリピート病であ り，原因遺伝子 FMR1 の 5 未端非翻訳領域における CGG リピート配列の異常伸長（55-200 リピート）によ り発症する遺伝性神経疾患である。リピート配列が形 成する G4RNA，もしくはへアピン型 RNA が RAN 翻 訳を惹起し, 翻訳産物であるグリシン反復タンパク質 が神経細胞に蓄積し，細胞毒性をもたらす(47)。

また, いくつかの G4 結合能を有するへリカーゼ ; $\operatorname{RecQ}$ ファミリーヘリカーゼ (BLM, WRN), ironsulfurへリカーゼ (RTEL1, DDX11, FANCJ, XPD), DEAH ボックスヘリカーゼ (DHX36, DHX9), SWI/SNF ファミリーヘリカーゼ (ATRX) は, G4 構造を不安定化 することが示唆されている $(48,49)$. それらの変異は, ゲノムの不安定性, 転写およびエピジェネティクス調 節に異常をきたし，様々な疾患を引き起こす $(48,49)$.

G4 結合性へリカーゼの中で, ATRX タンパク質はヒ トの脳機能に関与しており, ATRX 遺伝子の異常は $\mathrm{X}$ 連鎖 $\alpha$ サラセミア知的障害 (alpha thalassemia X-linked intellectual disability：ATR-X) 症候群を発症する (50-52).
ATRX タンパク質は，2つの主要ドメインである ATRXDNMT3-DNMT3L (ADD) ドメインとクロマチンリモ デリングドメインを持つ. ATRX タンパク質はヒスト ン H3K $9 \mathrm{me} 3$ と ADD ドメインを介して相互作用し, ヘテロクロマチンに局在する(53-55)。 また，クロマ チンリモデリングドメインは ATPase によるへリカー ゼ活性を有する $(56,57)$. ゲノムワイド解析では, ATRX タンパク質は rDNAリピート, テロメアリピート, ミニサテライト, 内因性レトロウイルス配列等, タン デムリピートでの局在が報告されている(58)。初代ヒ 卜赤血球細胞とマウス胚性幹細胞の ATRX ChIP-seq 解析では, ATRX タンパク質は特に G4DNA形成タン デムリピートで集積が見られる(59)。さらに，ATRX タンパク質は in vitro で Xist A リピート RNA(60) およ びテロメアリピート RNA(61) と直接相互作用する. しかしながら, G4 構造と直接結合する ATRX タンパ ク質の正確なモチーフは未だ同定されていない.

私達は, $A T R X$ 遺伝子変異による知的障害の原因を 追究するため, Atrx 遺伝子の exon2 を欠損させたATR-X 症候群モデルマウスを用いて脳機能解析を行った。学 習・記憶に重要な海馬組織において DNA マイクロア レイ解析を行ったところ, 母由来インプリント遺伝子 $X l r 3 b$ が脳特異的に有意に上昇していた。 その発現機 構として, $X l r 3 b$ 遺伝子の $\mathrm{CpG}$ island に存在する $\mathrm{G} 4$ 構 造にATRX-DNAメチルトランスフェラーゼ複合体が 結合し, DNAメチル化調節を行うことで $X l r 3 b$ の発現 を制御することを明らかにしたＸ１r3b タンパク質は 数種の RNA 結合タンパク質と結合し, 神経細胞の樹 状突起におけるカルシウムカルモジュリン依存性タン パク質キナーゼ II $\alpha$ （CaMKII $\alpha ）$ mRNA 輸送を抑制的 に調節すること，神経特異的 Xlr3b トランスジェニッ クマウスは学習障害を呈することを明らかにし, G4 構造異常によるATR-X症候群の知的障害機構の一端 を解明した(62-64). ATRXタンパク質は, このような 脳のインプリント遺伝子におけるエピジェネティック 修飾だけでなく，テロメア維持やDNA 複製にも重要 であることが報告されている(65). 生体における G4 構造と ATRX の相互作用の役割を明らかにするために は,さらなる研究が必要である。

\section{G4RNA と神経疾患}

G4DNA だけではなく, G4RNA も神経機能において 重要な役割を果たす。神経細胞の特定の mRNA は細 胞体から軸索と樹状突起に輸送され, シナプスで局所 的に翻訳される. mRNAの輸送・局所翻訳はシナプ ス可塑性や学習・記憶メカニズムの根底にあることが 
示唆されており，この過程が障害されると神経機能に 異常をきたす (66-69). バイオインフォマティクス解 析では, 樹状突起 mRNAの約 30\%が 3'-UTRに G4 構 造モチーフを持つことが報告されている $(70)$ 。代表的 な樹状突起 mRNAとして, シナプス後局在タンパク質 PSD-95 および CaMKII がある。それら mRNA は，3'UTR中に G4 構造を有し, G4RNA 構造の変異により樹 状突起への輸送が阻害される (70)。3'-UTRが欠損し た CaMKII $\alpha$ 変異マウスでは, CaMKII $\alpha$ mRNA が樹状 突起に輸送されず，記憶学習に障害を呈する (71).

軸索および樹状突起における mRNAの輸送は, G4RNAを認識しトランスに作用する RNA 結合タンパ ク質によって制御されている，G4 結合能を有するタン パク質のアミノ酸組成を比較すると，グリシン残基と アルギニン残基の 20 アミノ酸モチーフ（RGRGR GRGGG SGGSG GRGRG）を共有している。興味深い ことに, このモチーフは TAR DNA-binding protein 43 (TDP-43), fused in sarcoma (FUS), fragile X mental retardation protein（FMRP） などの神経障害の原因と なる RNA 結合タンパク質に見られるアルギニンーグ リシンリッチ領域（RGG ボックス）と類似している (72-74). 以下では, その中でも特に脳機能に深く関 与する FMRP について述べる (75).

FMRP は，知的障害を呈する遺伝性神経疾患である 脆弱 $\mathrm{X}$ 症候群の原因遺伝子 FMRI によってコードされ ている(76)。脆弱 X 症候群は, FMR1 遺伝子の 5'-UTR に扮けるCGGリピートの延長が原因で発症する. (200 リピート以上の伸長で脆弱 X症候群， 55-200 リ ピートの伸長で前述の FXTAS を発症する. ) 細胞内機 構は未だ不明であるが, 200 以上の CGGリピートの延 長により, FMRI 遺伝子プロモーターの過剩メチル化 が誘導され，転写阻害により FMRPの発現がほぼ見ら れなくなる (77)。神経細胞において, FMRPは樹状突 起 mRNA 翻訳を抑制する RNA 結合タンパク質であり, RNA 顆粒としてシナプスのポリソームに結合する (78-80)。興味深いことに, マウス脳において 432 個 の mRNA が FMRP と免疫共沈降され, それらの約 $70 \%$ が G4 構造配列を持つ(81-83). FMRPには 4 つ の RNA 結合モチーフ (3つの KH ドメインと 1 つの RGG ボックス) があり(84-86), X 線結晶解析により, RGG ボックスは G4RNA を安定化し, G4 構造形成を 促進することが示されている $(87,88)$.

FMRP の G4 構造結合能は, タンパク質の局所翻訳 に影響を与え, FXS の病態に関与することが示唆され ている。例えば, FMRPは $M A P 1 B, A P P, P P 2 A c$ mRNA の 5’-UTRに位置する G4 構造に結合し翻訳抑制を引き
起こす(89-92)，遺伝子発現の減少は G4RNA の安定性 と相関すると推測されており (93-94), mRNA の 5'-UTR 中の G4RNAは翻訳段階での遺伝子発現を抑制する可能 性がある。近年，リボソームプロファイリングにより， G4RNA 構造が上流オープンリーディングフレーム (upstream open reading frame：uORF) の翻訳を活性化 することによって, 本来のタンパク質コード配列での 翻訳を抑制することが示された(95)，一方で，Sem3F mRNA や Avpr1a mRNA においては, FMRPが 3'-UTR の $\mathrm{G} 4$ 構造に結合する $(81,96)$. FmrI ノックアウト細 胞では, Sem $3 F$ mRNA 及び Avprla mRNA とポリソー ムとの会合が減少することから (81), FMRPが翻訳活 性化因子として機能するか, または mRNAの安定性に 影響を及ぼすことが示唆される。

\section{6. 神経疾患における治療標的としての G4 構造}

これまで, 多種多様な G4 構造結合リガンドが同定 されており, がんを始めとした様々な疾患に対して治 療薬となる可能性が報告されている(97-99)，私達は， ポルフィリン骨格が G4 構造結合能を有する点に着 目し，プロトポルフィリン IX (protoporphyrin IX : PPIX) とへミンがATR-X症候群の治療薬として有効で あることを見出した (64).PPIX とへミンは細胞内で 5-アミノレブリン酸から産生される５-アミノレブリ ン酸を ATR-X 症候群モデルマウスに投与したところ, モデルマウスで見られる認知機能障害が有意に改善し た(64)。5-アミノレブリン酸は安全性の高い既承認薬 であることから (100)，ドラッグ・リポジショニング による ATR-X 症候群患者に対する臨床開発が望まれる.

G4C2 リピート RNAを標的とする G4 結合性小分子 リガンドやアンチセンスオリゴヌクレオチドは， RNA 結合タンパク質の集積による RNA 毒性を抑制し, RAN 翻訳を阻害することによって, C9ALS/FTD の神経症 状を改善する(101-103)，G4C2リピートRNAを標的 とした G4 結合リガンドの薬理学的研究は, 化合物が G4 構造を歪め, RAN 翻訳を抑制する可能性を示して いる.しかしながら，G4RNAが RAN 翻訳においてど のような役割を果たすのかは未だ明らかではない.

\section{7. 終わりに}

G4RNA に関しては，未だにその細胞内での存在や 機能は明らかではないが，G4DNA に関してはゲノム ワイド解析によって細胞内機能が明らかになりつつ ある。しかしながら, (1) G4DNA 形成は細胞の発達 段階によって変化するのか? (2) G4DNA 形成はエピ ジェネティクスとどのように関連しているのか？ 
(3) G4DNA 形成は G4 結合タンパク質によってどのよ うに制御されるのか? など，まだ数多くの疑問が残さ れている。細胞内において，G4DNA はワトソンーク リックの二本鎖立体配座と平衡を形成しながら核内の ヒストンタンパク質に結合するのに対し，G4RNAは 様々な RNA二次構造 (ヘアピン, バルジ, シュード ノット）や RNA 結合タンパク質と平衡を形成すると 予想されている。 また，RNAはDNAと異なり相補鎖を 欠いていることから, RNAはDNAよりも生体内で G4 構造を形成する傾向が強いと予想されている。 しかし ながら, 確たる証拠は未だ報告されていない. 神経細 胞の核内においては，G4DNA と神経特異的な転写修 飾，テロメア維持，およびエピジェネティクス修飾との 関連性について明らかにする必要がある（図 3a）(104). 薬理学的には, 細胞質において, G4 構造結合リガンド により, RNA foci 等の病原性 RNA と RNA 結合タンパ ク質の相互作用を抑制し, LLPS の正常化や RAN 翻訳 を阻害することができる（図 3b）(104）。また，G4 構造 結合リガンドは, 樹状突起（図 3c）および軸索（図 3d） mRNAの安定性, 翻訳, および細胞内局在を含む mRNA 代謝に影響を与える可能性がある (104)。G4 構造の生 物学的機能を基礎研究により解明することは, 医薬品 開発の新規ターゲットを社会に提示することに繋がる. また，冒頭でも述べたが，G4 構造はヒトゲノムだけで なく，他の生物種，例えばウイルスや原虫においても 研究が進められており, 本項で述べた神経疾患の枠に
留まらない. 現在の G4 研究は氷山の一角に過ぎず, 多くの科学的, 及び薬理学的発見がまだ残されている. 今後のさらなる研究の展開が期待される.

著者の利益相反：開示すべき利益相反はない.

\section{文献}

1) Watson JD, et al. Nature. 1953;171:737-738.

2) Wang AH, et al. Nature. 1979;282:680-686.

3) Gehring K, et al. Nature. 1993;363:561-565.

4) Sen D, et al. Nature. 1988;334:364-366.

5) Zhao J, et al. Cell Mol Life Sci. 2010;67:43-62.

6) Bang I. Biochem Z. 1910;26:293-231.

7) Gellert M, et al. Proc Natl Acad Sci U S A. 1962;48:2013-2018.

8) Sundquist WI, et al. Nature. 1989;342:825-829.

9) Williamson JR, et al. Cell. 1989;59:871-880.

10) Bochman ML, et al. Nat Rev Genet. 2012;13:770-780.

11) Song J, et al. Translation. 2016;4:e1244031.

12) Hänsel-Hertsch R, et al. Nat Rev Mol Cell Biol. 2017;18:279-284.

13) Fay MM, et al. J Mol Biol. 2017;429:2127-2147.

14) Kwok CK, et al. Trends Biotechnol. 2017;35:997-1013.

15) Mukherjee AK, et al. Trends Genet. 2019;35:129-144.

16) Deng H, et al. Biopolymers. 1995;35:677-681.

17) Kumar N, et al. Nucleic Acids Res. 2008;36:4433-4442.

18) Bhattacharyya D, et al. Front Chem. 2016;4:38.

19) Keniry MA, et al. Biopolymers. 2000-2001;56:123-146.

20) Yaku H, et al. Chem Commun. 2012;48:6203-6216.

21) Patel DJ, et al. Nucleic Acids Res. 2007;35:7429-7455.

22) Guiset Miserachs H, et al. J Biol Inorg Chem. 2016;21:975-986.

23) Joachimi A, et al. Bioorg Med Chem. 2009;17:6811-6815.

24) Zhang AY, et al. Biochemistry. 2011;50:7251-7258.

25) Huppert JL, et al. Nucleic Acids Res. 2005;33:2908-2916.

26) Kikin O, et al. Nucleic Acids Res. 2006;34:W676-W682.

27) Eddy J, et al. Nucleic Acids Res. 2006;34:3887-3896.

28) Yadav VK, et al. Nucleic Acids Res. 2008;36:D381-D385.

29) Beaudoin JD, et al. Nucleic Acids Res. 2014;42:1209-1223.

30) Bedrat A, et al. Nucleic Acids Res. 2016;44:1746-1759.
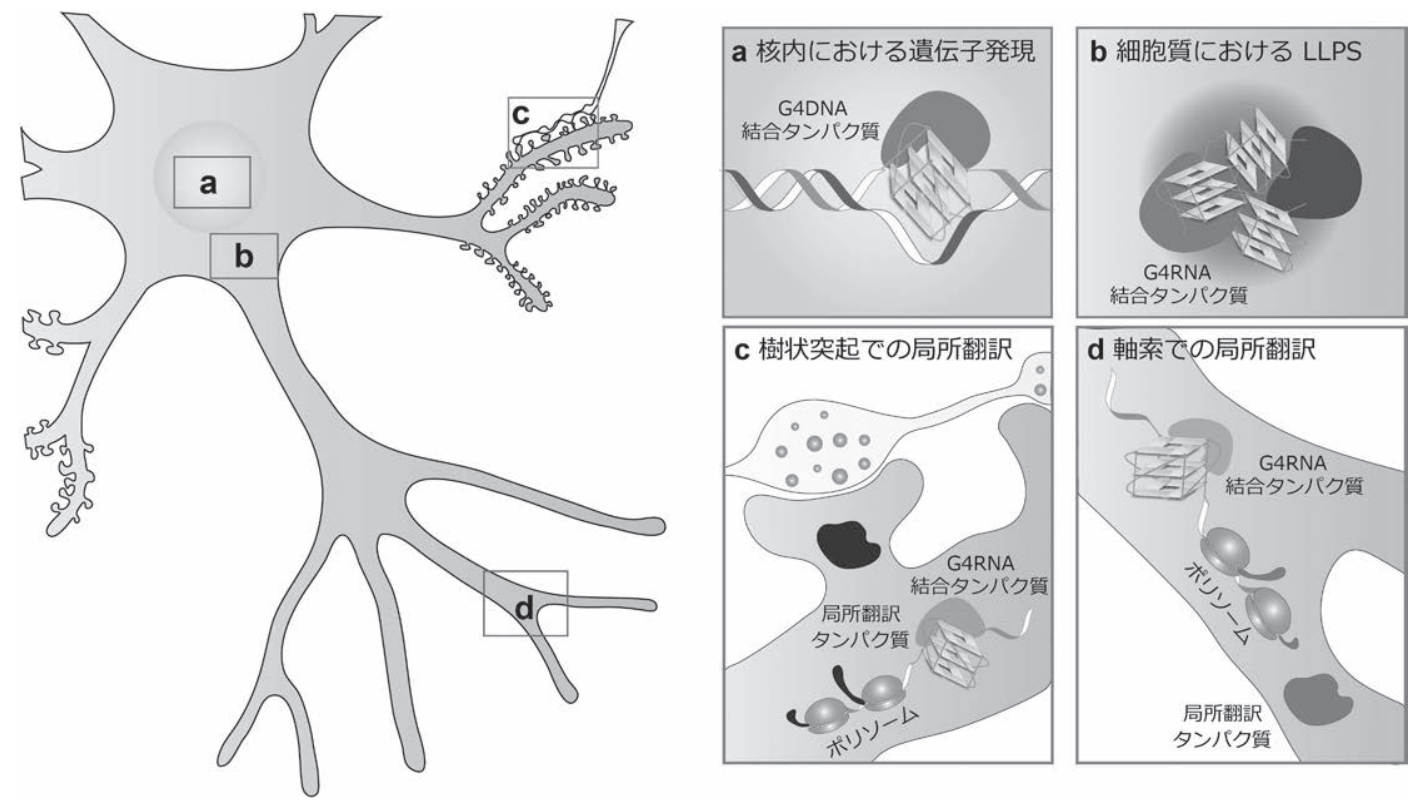

図 3 神経細胞におけるグアニン四重鎖構造の役割

（a）核内において，グアニン四重鎖はDNA グアニン四重鎖（G4DNA）結合タンパク質と共に，転写修飾，テロメア維持，およびエピジェネ ティクスに関与する. (b) 細胞質において, グアニン四重鎖は, RNA グアニン四重鎖（G4RNA）結合タンパク質との相互作用や液一液相分離 (liquid-liquid phase separation : LLPS) を介してRNA 代謝に関与する。（c, d) また，RNAグアニン四重鎖は樹状および軸索において mRNA の輸送，安定性，局所翻訳に関与する. (文献 104 より一部改変) 
31) Besnard E, et al. Nat Struct Mol Biol. 2012;19:837-844.

32) Kumari S, et al. Nat Chem Biol. 2007;3:218-221.

33) Mukundan VT, et al. J Am Chem Soc. 2013;135:5017-5028.

34) Garant JM, et al. Database. 2015; doi:10.1093/database/bav059.

35) Garant JM, et al. Bioinformatics. 2017;33:3532-3537.

36) Chambers VS, et al. Nat Biotechnol. 2015;8:877-881.

37) Biffi G, et al. Nat Chem. 2013;5:182-186.

38) Hänsel-Hertsch R, et al. Nat Genet. 2016;10:1267-1272.

39) Kwok CK, et al. Nat Methods. 2016;10:841-844.

40) Guo JU, et al. Science. 2016;353:aaf5371.

41) Kwok CK, et al. Cold Spring Harb Perspect Biol. 2018;10:a032284.

42) Maizels N. EMBO Rep. 2015;16:910-922.

43) Renton AE, et al. Neuron. 2011;72:257-268.

44) Fay MM, et al. Cell Rep. 2017;21:3573-3584.

45) Zu T, et al. Proc Natl Acad Sci U S A. 2013;110:E4968-E4977.

46) Ash PE, et al. Neuron. 2013;77:639-646.

47) Todd PK, et al. Neuron. 2013;78:440-455.

48) Singleton MR, et al. Annu Rev Biochem. 2007;76:23-50.

49) Valton AL, et al. Trends Genet. 2016;32:697-706.

50) Gibbons RJ, et al. Am J Hum Genet. 1992;51:1136-1149.

51) Gibbons RJ, et al. Cell. 1995;80:837-845.

52) Gibbons RJ, et al. Hum Mutat. 2008;29:796-802.

53) Argentaro A, et al. Proc Natl Acad Sci U S A. 2007;104:11939-11944.

54) Dhayalan A, et al. Hum Mol Genet. 2011;20:2195-2203.

55) Iwase S, et al. Nat Struct Mol Biol. 2011;18:769-776.

56) Picketts DJ, et al. Hum Mol Genet. 1996;5:1899-1907.

57) Mitson M, et al. Hum Mol Genet. 2011;20:2603-2610.

58) Gibbons RJ, et al. Nat Genet. 2000;24:368-371.

59) Law MJ, et al. Cell. 2010;143:367-378.

60) Sarma K, et al. Cell. 2014;159:869-883.

61) Chu HP, et al. Cell. 2017;170:86-101.

62) Shioda N, et al. J Neurosci. 2011;31:346-358.

63) Nogami T, et al. Hippocampus. 2011;21:678-687.

64) Shioda N, et al. Nat Med. 2018;24:802-813.

65) Clynes D, et al. Trends Biochem Sci. 2013;38:461-466.

66) Tiedge H. Neuron. 2005;48:1-6.

67) Sutton MA, et al. Cell. 2006;127:49-58.

68) Bramham CR, et al. Nat Rev Neurosci. 2007;8:776-789.
69) Martin KC, et al. Cell. 2009;136:719-730

70) Subramanian M, et al. EMBO Rep. 2011;12:697-704

71) Miller S, et al. Neuron. 2002;36:507-519.

72) Mishra SK, et al. Sci Rep. 2016;6:38144.

73) Ule J. Curr Opin Neurobiol. 2008;18:516-523.

74) Gerstberger S, et al. Nat Rev Genet. 2014;15:829-845.

75) Verkerk AJ, et al. Cell. 1991;65:905-914.

76) Coffee B, et al. Am J Hum Genet. 2009;85:503-514.

77) Pieretti M, et al. Cell. 1991;66:817-822.

78) Bassell GJ, Nat Neurosci. 2011;14:1492-1494.

79) Ashley CT, et al. Science. 1993;262:563-566.

80) Darnell JC, et al. Cell. 2011;146:247-261.

81) Darnell JC, et al. Cell. 2001;107:489-499.

82) Schaeffer C, et al. EMBO J. 2001;20:4803-4813.

83) Brown V, et al. Cell. 2001;107:477-487.

84) Siomi H, et al. Cell. 1993;74:291-298.

85) Siomi MC, et al. Mol Cell Biol. 1996;16:3825-3832

86) Myrick LK, et al. Hum Mol Genet. 2015;24:1733-1740.

87) Phan AT, et al. Nat Struct Mol Biol. 2011;18:796-804.

88) Vasilyev N, et al. Proc Natl Acad Sci U S A. 2015;112:E5391E5400.

89) Lu R, et al. Proc Natl Acad Sci U S A. 2004;101:15201-15206.

90) Menon L, et al. RNA. 2008;14:1644-1655.

91) Westmark CJ, et al. PLoS Biol. 2007;5:e52.

92) Castets M, et al. Hum Mol Genet. 2005;14:835-844.

93) Wieland M, et al. Chem Biol. 2007;14:757-763.

94) Halder K, et al. Nucleic Acids Res. 2009;37:6811-6817.

95) Murat P, et al. Genome Biol. 2018;19:229.

96) Menon L, et al. Nucleic Acids Res. 2007;35:5379-5392.

97) Asamitsu S, et al. Molecules. 2019;24:429.

98) Asamitsu S, et al. Chemistry. 2019;25:417-430.

99) Balasubramanian S, et al. Nat Rev Drug Discov. 2011:10:261-275.

100) Roberts DW, et al. Neurosurg Clin N Am. 2012;23:371-377.

101) Su Z, et al. Neuron. 2014;83:1043-1050.

102) Jiang J, et al. Neuron. 2016;90:535-550.

103) Gendron TF, et al. Sci Transl Med. 2017;9.

104) Asamitsu S, et al. Int J Mol Sci. 2019;20:pii:E2884.

\title{
The potential of G-quadruplexes as a therapeutic target for neurological diseases
}

\author{
Norifumi Shioda, Yasushi Yabuki, Sefan Asamitsu \\ Department of Genomic Neurology, Institute of Molecular Embryology and Genetics, Kumamoto University
}

\begin{abstract}
The most common form of DNA is a right-handed helix, the B-form DNA. DNA can also adopt a variety of alternative conformations, termed non-B-form DNA secondary structures, including the G-quadruplex (G4). Furthermore, non-canonical RNA G4 secondary structures are also observed. Recent bioinformatics analysis revealed genomic positions of G4. In addition, G4 formation may be associated with various biological functions, including DNA replication, transcription, epigenetic modification, and RNA metabolism. In this review, we focus on G4 structures in neuronal functions, which may have important roles reveal mechanisms underlying neurological disorders. In addition, we discuss the potential of G4s as a therapeutic target for neurological diseases.
\end{abstract}

